\title{
Exploring Tourists' Push and Pull Travel Motivations to Participate in Songkran Festival in Thailand as a Tourist Destination: A Case of Taiwanese Visitors
}

\author{
Lung Ming Tsai, Kongkidakarn Sakulsinlapakorn \\ Chinese Culture University, Taipei, Taiwan
}

\begin{abstract}
This study aims to identify travel motivations including push and pull motivations that positively and directly affected the decision-making of Taiwanese travelers in participating in Songkran Festival in Thailand as their cultural destination. A questionnaire survey was conducted with 388 Taiwanese respondents who have never participated in Songkran Festival in Thailand before. The lists consisted of 30 attributes representing push motivation (14 attributes) as “psychological factor”, pull motivation (13 attributes) as “destination factor”, and intention to participate (three attributes). Pearson's correlation and simple linear regression were used to examine the research hypotheses. As a result, push and pull motivations positively and directly affected the intention to participate in Songkran Festival in Thailand. For push motivation, Taiwanese visitors perceived that they want to relax and get experience in foreign land, and have enjoyable time with travel companion. For pull motivation, Taiwanese visitors perceived that there are many special events in Songkran Festival, the image of Songkran Festival, Thai food is delicious, and the people are friendly and courteous. The managerial implications were also made for tourism industry of Thailand in terms of examination motivations in implementing new market strategies, designing promotion, and decision-making about destination development.
\end{abstract}

Keywords: push motivation, pull motivation, intention to participate, Songkran Festival, Thailand

\section{Introduction}

Over the last decade, tourism industry plays the important role in countries all around the world and it is also a crucial part of the economic growth in each country. The growth of tourism sector has been significantly driven by political stability, higher income, potential tourism campaign, and other factors (Singh, 1997). Mazumder, Sultana, and Al-Mamun (2013) addressed that tourism industry currently takes the strong action in the developing countries in Southeast Asia countries such as Thailand, Singapore, Malaysia, Brunei, and Indonesia. Thailand gains a lot of advantages from the tourism industry including generating the income earnings, creating the job opportunity, promoting the inbound development, reducing the poverty among the region, and stimulating the economy (World Travel \& Tourism Council, 2014).

Lung Ming Tsai, Professor, Department of Tourism Management, Chinese Culture University. Email: clm4@faculty.pccu.edu.tw.

Kongkidakarn Sakulsinlapakorn, Master Student, Department of International Business Administration, Chinese Culture University. 
During years of 2009-2014, Thailand had a lot of situations occurred which were affected on Thailand's tourism industry including global recession and riots in 2009, riots and political issue in 2010, severe flood in 2011, the political demonstration ended in 2013, and military-ruled government in 2014 (Vanhaleweyk, 2014). Fortunately, Thailand has the potential location which is located in the middle of South East Asia; it ensures the steady growth of Thailand's tourism (Business Monitor International, 2014). Business Monitor International (2014) reported that Thailand tourism has the well-established tourism destination along with the significant inbound and outbound travel growth and the expansion of the tourism industry.

Tourism Authority of Thailand (TAT) Taipei Office has cooperated with Taiwanese media in order to promote Thai New Year and to stimulate the demand of Taiwanese tourists selecting Thailand as the tourist destination during that period. According to TAT (2014), Thailand is regarded as one of the famous tourist destinations for Taiwanese tourists, preferentially during the Songkran Festival period in 2014; the airline record reports revealed the air travel from Taiwan to Thailand significantly increased by $15 \%$. However, the number of Taiwanese tourists arrived to Thailand during 2009-2014 was still not stable, but mostly showed the positive numbers of tourists; except years of 2012-2014 where the number of the Taiwanese tourists had decreased by $11.93 \%$ and $21.79 \%$, respectively (Ministry of Tourism and Sports of Thailand, 2014).

\section{Cultural Tourism}

Cultural tourism has the significant roles in the world tourism in terms of enjoyment of the lifestyle of local people which is motivated by cultural intents, for example, learning tours, performing arts, festivals, cultural events, monuments sightseeing, and travel for pilgrimage (World Tourism Organization, 2004). Cultural tourism is regarded as one of the most growing tourism sectors worldwide (World Tourism Organization, 2004). Presently, tourists have been changing their traveling behaviors and they obviously regard more on the local communities, cultural heritage, clean and safety tourist destination, and environmental friendly (Popichit, Anuwichanont, Chuanchom, Serirat, \& Mechinda, 2013). Cultural tourism helps to promote the way of life learning, the pride of community, the ethnic groups, and supports family-owned business in those areas (Bachleitner \& Zins, 1999; Sudipta, Sarat, \& Babu, 2010). In general, the poor and remote communities have plenty of intangible cultural resources including customs, folklore, and are sometimes located not far from the famous heritage sites whose culture can drive the sustainable tourism development. If the public policy planners have the well-organized integration between the intangible and tangible cultural resources, this can lead to the prosperity of the inbound-tourism which is the tool for reducing the poverty and increasing the well-being of the people in the communities (World Tourism Organization, 2004).

\section{Songkran Festival}

Songkran means the movement that the sun enters into the Aries (the first sign of zodiac). Songkran Festival is one of the most popular festivals in Thailand and is also known as the Water Festival and Thai New Year among the foreigners which has been celebrated with the colorful cultural activities from generation to generation (Asia News Monitor, 2010; Eastman, n.d.). In fact, the hottest month of the year in Thailand is April. Therefore, the practice of throwing water in Thailand is for the sake of the belief that there will be plenty of rain for their rice-planting season throughout the year. It is a long holiday for Thai people to enjoy this traditional Thai New Year (Asia News Monitor, 2010). The festival is held from April 13 to April 15 annually (Suksawat, n.d.; Jimmy, 2015), but for the rural areas, they will celebrate for one week or more (Asia News 
Monitor, 2010). In 1948, Thai government had announced April 13 as the public holiday and later on, the government agreed to extend Songkran Festival period in order to let people celebrate this festival longer (Asia News Monitor, 2010), promoting Thai culture to the tourists and encouraging people who lived far from hometown to have the great time of love and care with their families. During Songkran Festival, people will get involved with many activities including splashing water among one another, wishing other people with the New Year blessing, watching the parades of the Buddha, dancing, and playing Thai local games (Suksawat, n.d.; Jimmy, 2015; Lonely Planet, 2013). Furthermore, there will be the chance for Thai people to make merit and consolidate among the community members (Asia News Monitor, 2010; Jimmy, 2015). This meaningful festival attracts people all around the world to come and enjoy the fun of water and inherit the full of ancient tradition (Pramotmaneerat, 2014). In Bangkok, Chiang Mai, and big cities of Thailand, the parade of the Buddha image will move along the street. People can sprinkle the scented water to the Buddha image in order to express the reverence (Suksawat, n.d.; Eastman, n.d.).

Thai people believed that good luck comes during this period and people will do clean the house for the sake of washing away the bad luck from the previous year, and they will also prepare the food to welcome the guests and give to the monks in order to welcome the good luck (Suksawat, n.d.; Jimmy, 2015; Eastman, n.d.). In the early morning, there will be the monks walking along the street and holding the alms-bowl through which people can put the food into the monk's alms-bowl and some people will even go directly to the temple and give food-offering there (Suksawat, n.d.; Eastman, n.d.; National Culture Commission, 2007). After the processes of making merit, people will transfer the merit to the ancestors by pouring water on the ground or near the tree root (Suksawat, n.d.). For the cultural celebration of Songkran, the Ministry of Culture of Thailand has the campaign to urge citizens to buy the scented water, Thai local face powder, garlands, Thai fabric clothes, and handicrafts for their beloved one (Asia News Monitor, 2010).

\section{Literature Review}

\section{Travel Motivation}

Mill and Morrison (1998), Moutinho (2000), and Nankervis and Kelly (2001) pointed that the motives of destination and leisure choices depend on the different causes and processes which link to the various sources of information to satisfy one's needs. Generally, the decision-making process is mainly affected by the individual characteristics of each traveler (Beard \& Ragheb, 1983; Nankervis \& Kelly, 2001). In the same way, it is not necessary to process the similarity of external stimuli from two individuals. A crucial variation needs to be made between the common aims of travel, also known as overt factors and covert factors which indicate the more intensive psychological elements towards individual choice and preference (Nankervis \& Kelly, 2001; Awaritefe, 2003). Moreover, the identical motivation that affects the decision to travel may cause from the same discretionary income on household goods, etc. (Nankervis \& Kelly, 2001). The crucial element of destination management is to perceive the attitudes, values, preferences, and expectations of the visitor (Beard \& Ragheb, 1983; Nankervis \& Kelly, 2001). Even though the expectations are usually based on tourists' perception of the ability of the destination to meet their needs (Nankervis \& Kelly, 2001; Bowen \& Clarke, 2009), tourism industry is frequently influenced by its structure such as the impact of the advertising slogans, the copy in travel brochure in determining visitor expectations (Nankervis \& Kelly, 2001). 


\section{Push Motivation}

Push motivation is considered as the personal driver which allures an individual to travel under one's reasons such as escape from the daily routine, a need to spend quality time with the family, or the lust for adventure (Dann, 1977; Chon, 1989). Push motivation is the cause of the travel decision-making which will satisfy the internal motives of the travelers (Niemelä, 2010). The major two push motivations for tourism are the need to escape from the stresses and the need for the status along with the feelings of superiority (Dann, 1977). The outstanding push motivation in travel purposes is associated with the social interaction and elevation of kinship relationships, as well as the relaxation purposes on exploring the new things, new site, and people. The desire of travel can also be linked to the push motivation (Kanagaraj \& Bindu, 2013).

The study of international tourists travelling to Thailand including the top three tourist nationalities from its survey (United States of America, United Kingdom, and Australia) revealed that getting experience in foreign land is the most important push motivation among international tourists followed by: learn new culture, relax in foreign land, want to learn new things, interested in Thai culture, escape from same daily life, enjoy activities, and adventure. However, the motivation with the lowest mean score is adventure (Yiamjanya \& Wongleedee, 2014). A study of English, French, German, Italian, and South African tourists travelling to Mauritius found that rest and relaxation is the most important push motivation followed by nostalgia, escape, novelty, and social interaction. The push motivation result of this study is not the same with the previous study because each tourist has his/her own reasons for travelling (Kassean \& Gassita, 2013). A study of push motivation on foreign tourists to Jordan argued that the needs for prestige and social interactions are the most significant attributes that appeal the tourists to travel (Mohammad \& Som, 2010). A study of Thai tourists traveling to Europe found that the desire to experience Europe landscapes affects significantly Thai tourists' decision to choose Europe as the tourist destination (Chaipinit \& Phetvaroon, 2011).

\section{Pull Motivation}

Pull motivation is stimulated by the destination forces including attractions of scenery, historical sites, recreation facilities, cultural attractions, etc. (Sirakaya, Sheppard, \& McLellan, 1997; Kanagaraj \& Bindu, 2013). Pull motivation is the factor that attracts tourists to select the destination site. Furthermore, a tourist's view of a particular destination can be perceived as pull motivation (Niemelä, 2010).

The study of Yiamjanya and Wongleedee (2014) stated that Thai food and traditional markets were the only pull motivations which attracted international tourists to consider Thailand as a tourist destination. Thai food is popular for the international tourists and attracts tourists to visit Thailand. Good weather was revealed to have the least mean score of pull motivation. The study of foreign leisure tourists returning to Ho Chi Minh City, Vietnam found that the pull motivation had the remarkable impact on tourists' return intention than push motivation. In this study, the personal needs of tourists do not affect tourists' return intention, but the destination image is the factor that attracted tourists to return to Vietnam again. Moreover, the external forces of Vietnam attributes affected directly tourists' decision to return to Vietnam again in the future (Khuong \& Ha, 2014). A study of English, French, German, Italian, and South African tourists travelling to Mauritius found that beaches, climate and weather, landscape and exotic scenery of the island, Mauritian hospitality, and accommodation services offered to the travelers are the top five of pull motivations which attract tourists to choose Mauritius as a tourist destination (Kassean \& Gassita, 2013). A study of foreign tourists traveling to Jordan found that Jordan obviously has a lot of potential factors which can prolong tourists' stay, consuming, 
and promoting revisit behavior. The tourists regarded Jordan as an affordable and safe destination with nice environment and people hospitality. Jordan needs to focus on the heritage sites, natural attractions, cuisine, and culture; these attributes can help Jordan to attract more tourists (Mohammad \& Som, 2010). The study of pull motivation of Thai tourists traveling to Europe found that discovering new places, discovering different cultures and lifestyles, enriching themselves intellectually, and increasing their knowledge and desire to try something new are the attributes which increased the demand of Thai tourists traveling to Europe (Chaipinit \& Phetvaroon, 2011). The study of Kassean and Gassita (2013) revealed that tourist's personal preferences and personality types have an impact on selecting travel destinations.

\section{Intention to Participate}

The visitor retention is the significant factor for most of tourism organizations' profitability. The reasoned action theory introduced that behavior is specified by the tourist's subjective behavior to whether intend to travel or not (Zeithaml, Bitner, \& Gremler, 2009). The subjective probability of an individual is referred to future behavioral intention that an individual will take some action in the future (Ajzen, 2001; Kaplanidou \& Vogt, 2006; Zeithaml et al., 2009). Furthermore, the willingness of an individual to recommend goods/services to other people and repurchase intention is also perceived as future behavioral intention (Zeithaml et al., 2009). The service quality is the result of the positive and negative behavioral intention (Lam \& Hsu, 2006; Sparks, 2007; Canny \& Hidayat, 2012). Behavioral intention is specified by the attitude of an individual to take an action toward the behavior and subjective norm (Lam \& Hsu, 2006; Sparks, 2007; Canny \& Hidayat, 2012). For this reason, the angles of future behavioral intention can be found in all directions (Canny \& Hidayat, 2012). The level of future behavioral intention in the specific destination is habitually the consequence of tourist intention to revisit and the willingness to recommend in the certain destination (Chen \& Tsai, 2007). In addition, the measurement of future behavioral intention is evaluated differently on willingness to recommend, word-of-mouth, and revisit the certain destination (Lee, Jeon, \& Kim, 2011). In general, the behavioral intention to visit and travel is considered as one of the most important dependent variables, implying directly the possibility of potential travelers to possibly visit the destination (Ng, Lee, \& Soutar, 2007).

\section{Methodology}

\section{Research Framework}

The research framework for this study is shown in Figure 1 as follows.

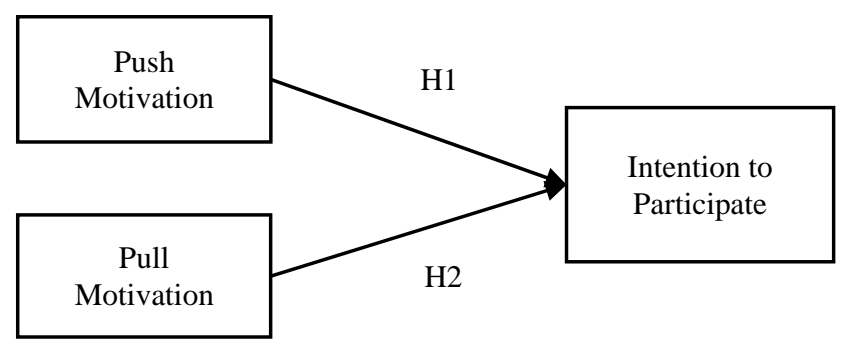

Figure 1. Research framework.

\section{Research Hypotheses}

H1: Push motivation is hypothesized to positively and directly affect tourist's intention to participate in Songkran Festival in Thailand. 
H2: Pull motivation is hypothesized to positively and directly affect tourist's intention to participate in Songkran Festival in Thailand.

\section{Questionnaire Design}

This study has developed the survey questionnaire to acquire the responses from Taiwanese people. The questionnaire was also made in Chinese version for the ease of respondent to answer. The questions were divided into four parts, including demographic information (six items), push motivation (14 items), pull motivation (13 items), and intention to participate (three items). All of the items were measured on a 5-point Likert scale. Respondents were asked to indicate their level of agreement toward each statement, from $1=$ strongly disagree to 5 = strongly agree. All of questions were tested to ensure the reliability and validity of the constructs.

\section{Data Analysis Procedures}

In this study, the data analysis procedures included Pearson correlation and regression analysis. In addition, in order to get the results from the hypothesis tests and the collected data, the SPSS will be used to analyze the data. The data analysis procedures are conducted by the following methods.

Pearson's correlation coefficient. Correlation analysis is a method used to examine the relationship among the variables in order to know how strong the relationship is. It is also a method used to analyze the interval or ratio scale. The most common measurement in correlation statistics is Pearson correlation or Pearson product moment correlation (PPMC). The Pearson coefficient indicates the same way as a correlation coefficient that is used in linear regression which shows the value from -1 to +1 . A value of +1 indicates a perfect positive relationship where a value of -1 indicates a perfect negative relationship between two or more variables and 0 indicates the non-relationship among the variables (Andale, 2012a). The high correlation ranges from 0.5 to 1.0 or -0.5 to 1.0 , medium correlation ranges from 0.3 to 0.5 or -0.3 to 0.5 , and low correlation ranges from 0.1 to 0.3 or -0.1 to -0.3 . The closer the value of $r$ approaches 0 , the more the variation the data points are around the line of best fit (Andale, 2012a; 2012b).

Simple linear regression. Simple linear regression method is a statistical process for estimating the future values of dependent variable by using SPSS program. It integrated a lot of techniques for modeling and analyzing many variables. According to Geladi and Kowalski (1986), the regression analysis focuses on the relationship between a dependent variable and one or more independent variables.

\section{Results and Discussion}

\section{Descriptive Analysis}

In this study, the data were collected by delivering one by one questionnaire survey from Taiwanese people in Taipei areas, Taiwan. This survey was conducted from January 18, 2015 to February 22, 2015. A total of 388 valid respondents from 400 responded the questionnaires who are Taiwanese travelers that have never participated in Songkran Festival in Thailand before.

Characteristics of the respondents. This section illustrates the information about the characteristics of the respondents as shown in Table 1. This table shows the basic characteristics of the 388 respondents, including gender, marital status, age, education level, occupation, and income per month. As can be seen, $50.77 \%$ of the respondents are male, and $49.23 \%$ of the respondents are female. Most of the respondents are single (43.30\%), followed by in partnership (32.22\%), married (21.39\%), and divorced (3.09\%). Besides, most of the respondents' age is between 18 and 25 years old (37.11\%), followed by 26 to 35 years old (27.84\%), 
less than 18 years old (11.34\%), 36 to 45 years old (9.79\%), 46 to 55 years old (8.76\%), and more than 55 years old (5.16\%). Concerning the education level, $56.96 \%$ of the respondents held bachelor's degree, followed by high school or lower (22.94\%), master's degree (16.75\%), and doctoral degree (3.35\%). The largest demographic group is students (47.68\%), followed by management and professional (21.91\%), freelance/part time (19.59\%), self-employed (6.44\%), and housewife (4.38\%). As for the income, $28.61 \%$ of the respondents had an income of 30,001-60,000 NTD per month, followed by 3,001-15,000 NTD (28.35\%), less than 3,000 NTD (17.78\%), 15,001-30,000 NTD (13.66\%), and above 60,000 NTD (11.60\%).

Table 1

Characteristics of Respondents

\begin{tabular}{|c|c|c|}
\hline Classification & Frequency & Percentage (\%) \\
\hline \multicolumn{3}{|l|}{ Gender } \\
\hline Male & 197 & 50.77 \\
\hline Female & 191 & 49.23 \\
\hline \multicolumn{3}{|l|}{ Marital status } \\
\hline Single & 168 & 43.30 \\
\hline Married & 83 & 21.39 \\
\hline In partnership & 125 & 32.22 \\
\hline Divorced & 12 & 3.09 \\
\hline \multicolumn{3}{|l|}{ Age } \\
\hline Less than 18 & 44 & 11.34 \\
\hline $18-25$ & 144 & 37.11 \\
\hline 26-35 & 108 & 27.84 \\
\hline $36-45$ & 38 & 9.79 \\
\hline $46-55$ & 34 & 8.76 \\
\hline More than 55 & 20 & 5.16 \\
\hline \multicolumn{3}{|l|}{ Education level } \\
\hline High school or lower & 89 & 22.94 \\
\hline Bachelor degree & 221 & 56.96 \\
\hline Master degree & 65 & 16.75 \\
\hline Doctoral degree & 13 & 3.35 \\
\hline \multicolumn{3}{|l|}{ Occupation } \\
\hline Student & 185 & 47.68 \\
\hline Unemployment & 0 & 0 \\
\hline Management and professional & 85 & 21.91 \\
\hline Self-employed & 25 & 6.44 \\
\hline Housewife & 17 & 4.38 \\
\hline Freelance/part-time & 76 & 19.59 \\
\hline \multicolumn{3}{|l|}{ Income per month (NTD) } \\
\hline Less than 3,000 & 69 & 17.78 \\
\hline $3,001-15,000$ & 110 & 28.35 \\
\hline $15,001-30,000$ & 53 & 13.66 \\
\hline $30,001-60,000$ & 111 & 28.61 \\
\hline 60,000 or above & 45 & 11.60 \\
\hline
\end{tabular}

Measurement results of relevant variables. Table 2 illustrates the descriptive statistics which related to mean values and standard deviations. In this study, Taiwanese tourists realized that to relax in foreign land is the most important push motivation which was reflected by the highest mean score of 4.106 . The lowest mean 
score is to find thrills and excitement (3.858). For pull motivation, Taiwanese tourists realized that there are many special events in Songkran Festival with the highest mean score of 4.121 and the least important is that Thailand is a safe destination with the lowest mean score of 3.874. For the last variable intention to participate, "I am willing to participate in Songkran Festival in the future" has the highest mean score of 4.186 and "I will encourage my family and friends to participate in Songkran Festival” has the lowest mean of 3.936.

Table 2

Descriptive Analysis of Variables

\begin{tabular}{|c|c|c|c|}
\hline Attributions of push motivation & Rank & Mean & Std. dev. \\
\hline To relax in foreign land & 1 & 4.106 & 0.775 \\
\hline To get experience in foreign land & 2 & 4.092 & 0.827 \\
\hline To have enjoyable time with my travel companion(s) & 3 & 4.085 & 0.839 \\
\hline To learn new culture & 4 & 4.083 & 0.793 \\
\hline To see how people of different cultures live & 5 & 4.077 & 0.770 \\
\hline To satisfy the desire to be somewhere else & 6 & 4.020 & 0.794 \\
\hline To sightsee touristic spots & 7 & 4.005 & 0.791 \\
\hline To exchange custom and traditions & 8 & 3.995 & 0.781 \\
\hline To visit a place that my friends have been to & 8 & 3.995 & 0.797 \\
\hline To meet new friends & 9 & 3.984 & 0.800 \\
\hline To escape from same daily life & 10 & 3.979 & 0.800 \\
\hline To participate in new activities & 11 & 3.915 & 0.839 \\
\hline To increase my social status & 12 & 3.863 & 0.917 \\
\hline To find thrills and excitement & 13 & 3.858 & 0.920 \\
\hline Attributions of pull motivation & Rank & Mean & Std. dev. \\
\hline There are many special events in Songkran Festival & 1 & 4.121 & 0.793 \\
\hline The image of Songkran Festival is wonderful & 2 & 4.103 & 0.777 \\
\hline Thai food is delicious & 3 & 4.095 & 0.753 \\
\hline In Thailand, people are very friendly and courteous & 3 & 4.095 & 0.796 \\
\hline Participating in the Songkran Festival will provide a unique experience for me & 4 & 4.067 & 0.804 \\
\hline Participating in the Songkran Festival in Thailand is affordable for me & 5 & 4.059 & 0.689 \\
\hline Outdoor activities & 6 & 4.039 & 0.791 \\
\hline Participating in Songkran Festival can experience exotic atmosphere & 7 & 4.034 & 0.792 \\
\hline In Songkran Festival, the service is very good & 8 & 4.021 & 0.803 \\
\hline The Songkran Festival is well-established & 9 & 3.987 & 0.796 \\
\hline The culture, arts, and traditions of Thailand & 10 & 3.982 & 0.808 \\
\hline Songkran Festival is a suitable activity for entire family & 11 & 3.967 & 0.801 \\
\hline Thailand is a safe destination & 12 & 3.874 & 0.792 \\
\hline Attributions of intention to participate & Rank & Mean & Std. dev. \\
\hline I am willing to participate in Songkran Festival in the future & 1 & 4.186 & 0.782 \\
\hline I consider participating in Songkran Festival as the first on my list of cultural destination in Thailand & 2 & 4.129 & 0.853 \\
\hline I will encourage my family and friends to participate in Songkran Festival & 3 & 3.936 & 0.831 \\
\hline
\end{tabular}

\section{Item Analysis and Reliability Tests}

The exploratory factor analysis (EFA) and reliability test were adopted to identify the inter-relationship among the set of research variables and to verify their reliability and validity. Furthermore, two EFAs were determined with Kaiser-Meyer-Olkin (KMO) and Bartlett's test and Varimax Rotation of 27 items of independent variables and three items of dependent variables. 
Push motivation. Table 3 illustrates the results of item analysis and reliability test on push motivation of Taiwanese tourists. As a result, the measurement of sampling adequacy (KMO) for push motivation is 0.898 which is greater than 0.60. In addition, Bartlett's test of sphericity displays the value of significance of push motivation as 0.000 . In this study, the factor loadings of push motivation (independent variable) exceeded 0.40 which range from 0.426 to 0.990 . The Cronbach's alpha of push motivation is 0.935 (greater than 0.7). Therefore, it can be concluded that all items are acceptable.

Table 3

Results of Item Analysis and Reliability Test on Push Motivation

\begin{tabular}{|c|c|c|c|}
\hline Variables & $\begin{array}{l}\text { Factor } \\
\text { loadings }\end{array}$ & $\begin{array}{l}\text { Cronbach's alpha } \\
\text { if item deleted }\end{array}$ & $\begin{array}{l}\text { Cronbach's } \\
\text { alpha }\end{array}$ \\
\hline Push motivation (PUSH) & & & 0.935 \\
\hline To get experience in foreign land & 0.480 & 0.934 & \\
\hline To learn new culture & 0.426 & 0.934 & \\
\hline To relax in foreign land & 0.481 & 0.933 & \\
\hline To escape from same daily life & 0.965 & 0.926 & \\
\hline To meet new friends & 0.973 & 0.926 & \\
\hline To participate in new activities & 0.479 & 0.933 & \\
\hline To increase my social status & 0.708 & 0.931 & \\
\hline To satisfy the desire to be somewhere else & 0.958 & 0.927 & \\
\hline To exchange custom and traditions & 0.429 & 0.934 & \\
\hline To find thrills and excitement & 0.697 & 0.931 & \\
\hline To sightsee touristic spots & 0.990 & 0.926 & \\
\hline To see how people of different cultures live & 0.539 & 0.931 & \\
\hline To have enjoyable time with my travel companion(s) & 0.641 & 0.928 & \\
\hline To visit a place that my friends have been to & 0.989 & 0.926 & \\
\hline
\end{tabular}

Table 4

Results of Item Analysis and Reliability Tests on Pull Motivation

\begin{tabular}{|c|c|c|c|}
\hline Variables & $\begin{array}{l}\text { Factor } \\
\text { loadings }\end{array}$ & $\begin{array}{l}\text { Cronbach’s alpha } \\
\text { if item deleted }\end{array}$ & $\begin{array}{l}\text { Cronbach's } \\
\text { alpha }\end{array}$ \\
\hline Pull motivation (PULL) & & & 0.788 \\
\hline Thai food is delicious & 0.662 & 0.769 & \\
\hline Image of Songkran Festival is wonderful & 0.751 & 0.764 & \\
\hline In Songkran Festival, the service is very good & 0.813 & 0.762 & \\
\hline In Thailand, people are very friendly and courteous & 0.785 & 0.770 & \\
\hline The Songkran Festival is well-established & 0.984 & 0.761 & \\
\hline Participating in the Songkran Festival in Thailand is affordable for me & 0.615 & 0.779 & \\
\hline There are many special events in Songkran Festival & 0.689 & 0.790 & \\
\hline Participating in the Songkran Festival will provide a unique experience for me & 0.796 & 0.767 & \\
\hline The culture, arts, and traditions of Thailand & 0.467 & 0.784 & \\
\hline Songkran Festival is a suitable activity for entire family & 0.986 & 0.761 & \\
\hline Thailand is a safe destination & 0.686 & 0.789 & \\
\hline Outdoor activities & 0.716 & 0.786 & \\
\hline Participating in Songkran Festival can experience exotic atmosphere & 0.461 & 0.777 & \\
\hline
\end{tabular}


Pull motivation. Table 4 above illustrates the results of item analysis and reliability test on pull motivation of Taiwanese tourists. As a result, the measurement of sampling adequacy (KMO) for pull motivation is 0.683 which is greater than 0.60 . In addition, Bartlett's test of sphericity displays the value of significance of push motivation as 0.000 . In this study, the factor loadings of pull motivation (independent variable) exceeded 0.40 which range from 0.461 to 0.986 . The Cronbach's alpha of pull motivation is 0.788 (greater than 0.7 ). Therefore, it can be concluded that all items are acceptable.

Intention to participate. Table 5 illustrates the results of item analysis and reliability test on intention to participate of Taiwanese tourists. As a result, the measurement of sampling adequacy (KMO) for intention to participate is 0.712 which is greater than 0.60. In addition, Bartlett's test of sphericity displays the value of significance of intention to participate as 0.000 . In this study, the factor loadings of intention to participate (dependent variable) exceeded 0.40 which range from 0.742 to 0.847 . The Cronbach's alpha of intention to participate is 0.865 (greater than 0.7). Therefore, it can be concluded that all items are acceptable.

Table 5

Results of Item Analysis and Reliability Tests on Intention to Participate

\begin{tabular}{|c|c|c|}
\hline $\begin{array}{l}\text { Factor } \\
\text { loadings }\end{array}$ & $\begin{array}{l}\text { Cronbach's alpha } \\
\text { if item deleted }\end{array}$ & Cronbach’s alpha \\
\hline Intention to participate & & 0.865 \\
\hline $\begin{array}{l}\text { I am willing to participate in Songkran Festival in the } 0.776 \\
\text { future }\end{array}$ & 0.824 & \\
\hline $\begin{array}{l}\text { I consider participating in Songkran Festival as the first on } 0.742 \\
\text { my list of cultural destination in Thailand }\end{array}$ & 0.851 & \\
\hline $\begin{array}{l}\text { I will encourage my family and friends to participate in } 0.847 \\
\text { Songkran Festival }\end{array}$ & 0.751 & \\
\hline
\end{tabular}

\section{Pearson's Correlation Analysis}

The results of Table 6 revealed that there was a strongly positive relationship ( $r=+0.40$ to +0.69$)$ between the dependent variable of intention to participate and the independent variables: push motivation $(r=0.652$, $p<0.01)$ and pull motivation $(r=0.475, p<0.01)$.

Table 6

Results of Pearson's Correlation Analysis

\begin{tabular}{|c|c|c|c|c|}
\hline & & Push motivation & Pull motivation & Intention to participate \\
\hline \multirow{3}{*}{ Push motivation } & Pearson correlation & 1 & $0.663^{* *}$ & $0.652^{* *}$ \\
\hline & Sig. (2-tailed) & & 0.000 & 0.000 \\
\hline & $N$ & 388 & 388 & 388 \\
\hline \multirow{3}{*}{ Pull motivation } & Pearson correlation & $0.663^{* *}$ & 1 & $0.475^{* *}$ \\
\hline & Sig. (2-tailed) & 0.000 & & 0.000 \\
\hline & $N$ & 388 & 388 & 388 \\
\hline \multirow{3}{*}{$\begin{array}{l}\text { Intention to } \\
\text { participate }\end{array}$} & Pearson correlation & $0.652^{* *}$ & $0.475^{* *}$ & 1 \\
\hline & Sig. (2-tailed) & 0.000 & 0.000 & \\
\hline & $N$ & 388 & 388 & 388 \\
\hline
\end{tabular}

Note. ${ }^{* *}$ : Correlation is significant at the 0.01 level (2-tailed). 


\section{Simple Linear Regression}

The regression analysis focuses on the relationship between a dependent variable and one or more independent variables (Geladi \& Kowalski, 1986). In this study, independent variables are push motivation and pull motivation, and the dependent variable is intention to participate. There are two hypotheses including H1: Push motivation is hypothesized to positively and directly affect tourist's intention to participate in Songkran Festival in Thailand and H2: Pull motivation is hypothesized to positively and directly affect tourist's intention to participate in Songkran Festival in Thailand.

Relationship between push motivation and intention to participate. H1 predicts that push motivation is hypothesized to positively and directly affect tourist's intention to participate in Songkran Festival in Thailand. There are 14 items that are used for push motivation. According to Table 7, push motivation has a positive impact on intention to participate $(\beta=0.652, p<0.001), R^{2}$ is greater than 0.1 with $p$-value of $0.000, F$-value is greater than 4, Durbin-Watson is between 1.5 and 2.5. H1 is significant as $t$-test results have shown that the $p$-value is less than 0.05 . Lastly, since the probability of the $F$-statistic has a $p$-value of $0.000, \mathrm{H} 1$ is supported.

Table 7

Regression of Push Motivation - Intention to Participate

\begin{tabular}{lllll}
\hline Predictor & $\beta$ & $t$ & $\mathrm{D}-\mathrm{W}$ & $p$ \\
\hline Push motivation & 0.652 & 16.899 & 2.100 & $0.000^{* * *}$ \\
\hline
\end{tabular}

Note. $R^{2}=0.425 ; F=285.589 ;{ }^{* * *}: p<0.001,{ }^{* * *}: p<0.010,{ }^{*}: p<0.05$.

Relationship between pull motivation and intention to participate. H2 predicts that pull motivation is hypothesized to positively and directly affect tourist's intention to participate in Songkran Festival in Thailand. There are 13 items that are used for pull motivation. According to Table 8, pull motivation has a positive impact on intention to participate $(\beta=0.475, p<0.001), R^{2}$ is greater than 0.1 with $p$-value of $0.000, F$-value is greater than 4, Durbin-Watson is between 1.5 and 2.5. H2 is significant as $t$-test results have shown that the $p$-value is less than 0.05 . Lastly, since the probability of the $F$-statistic has a $p$-value of $0.000, \mathrm{H} 2$ is supported.

Table 8

Regression of Pull Motivation - Intention to Participate

\begin{tabular}{lllll}
\hline Predictor & $\beta$ & $t$ & $\mathrm{D}-\mathrm{W}$ & $p$ \\
\hline Pull motivation & 0.475 & 10.606 & 1.927 & $0.000^{* * * *}$ \\
\hline Note. $R^{2}=0.226 ; F=112.480 ;{ }^{* * *}: p<0.001,{ }^{* * *}: p<0.010,{ }^{*}: p<0.05$. & & &
\end{tabular}

\section{Conclusion}

The research objective is to investigate the relationship among push motivation, pull motivation, and intention to participate. Based on the analysis discussed in the previous chapter, the results of hypotheses testing are summarized in Table 9.

Table 9

Hypotheses and Results of Empirical Test

\begin{tabular}{|l|l|l|}
\hline & Research hypotheses & Results \\
\hline H1 & $\begin{array}{l}\text { Push motivation is hypothesized to positively and directly affect tourist's intention to } \\
\text { participate in Songkran Festival in Thailand }\end{array}$ & Supported \\
\hline H2 & $\begin{array}{l}\text { Pull motivation is hypothesized to positively and directly affect tourist's intention to } \\
\text { participate in Songkran Festival in Thailand }\end{array}$ & Supported \\
\hline
\end{tabular}


In conclusion, the statistical findings showed that push and pull motivations positively and directly affected intention to participate. However, Taiwanese perceived push motivation to have more significant influence on intention to participate than pull motivation. Most of them perceived on push motivation that they want "to relax in foreign land" as the first rank; along with "to get experience in foreign land" and "to have enjoyable time with my travel companion" in the second and third ranks, while the lowest rank was "to find thrills and excitement". For pull motivation, Taiwanese tourists perceived "There are many special events in Songkran Festival" as the top rank; along with the second rank "the image of Songkran Festival is wonderful" then, "Thai food is delicious", and "In Thailand, people are very friendly and courteous" in the third rank, but "Thailand is a safe destination" was in the lowest rank. The top rank of intention to participate revealed that "I am willing to participate in Songkran Festival in the future". This showed that in the future, Taiwanese tourists will surely participate in Songkran Festival in Thailand.

Based on the data analysis results, all of the hypotheses and proposed model are supported which provided the significance of the research conceptual framework to positive direction. This implies that when the tourists have strong intrinsic desires to go for one destination and have the perception on features, attractions, or attributes of a specific destination, they tend to have the high level of intention to visit the destination or participate in the activity in the future. Furthermore, $\mathrm{H} 1$ that push motivation positively and directly affected tourist's intention to participate in Songkran Festival in Thailand, and $\mathrm{H} 2$ that pull motivation positively and directly affected tourist's intention to participate in Songkran Festival in Thailand are also supported by the previous studies of Qiao, Chen, Guan, and Kim (2008), Kim (2008), Lee et al. (2011), Tang (2014), and Pratminingsih, Rudatin, and Rimenta (2014). According to them, travel motivation includes push motivation (internal or psychological factor) and pull motivation (external or destination factor), both of which significantly affected the intention to visit a specific destination or participate in a specific event in the future.

\section{Managerial Implications}

The major findings of this study have the significant managerial implications for destination marketers, business organizations in tourism sector, and government in Thailand.

First, the results found that Taiwanese tourists demand to go for Songkran Festival because they desire to relax in foreign land, to get experience in foreign land, to have enjoyable time with travel companion, to learn new culture, and to see how people of different cultures live. This knowledge can be the guideline for creating the new marketing strategies in order to support both supply and demand markets and enhance the destination image. Second, the study reconfirms that Taiwanese tourists are influenced by the special events in Songkran Festival, the image of Songkran Festival, Thai food, friendly and courteous people, and uniqueness of experience. In order to increase the efficiency in marketing of Songkran Festival for Taiwanese tourists, marketing teams should focus on the image and uniqueness of Songkran Festival. To achieve this, marketing teams should present the background that features the image of the diversity and the charms of Songkran Festival. Tourism companies may also launch the attractive Songkran Festival packages and provide more choices to meet the demand of the potential travelers. Third, the study also found that Taiwanese people perceived that Thailand is not a safe tourist destination. This is one of the top weaknesses of Thailand tourism in terms of tourists' perception. The national tourism authority should raise the perception of the Taiwanese travelers in terms of safety and security by launching new policies to ensure the safety for the potential travelers. Therefore, Thailand destination image in the perception of Taiwanese travelers will become more attractive 
rather than other cultural destinations. Fourth, each sector should pay attention to both intrinsic and extrinsic reasons why Taiwanese tourists make a decision to participate in Songkran Festival, and their needs and expectations about the vacation as well. Thailand tourism sectors should promote the Songkran Festival advertisement and launch more attractive programs/activities through social media, websites, and video clips to raise the Taiwanese tourist's travel motivation. Finally, this study helps identify the tourists' problems and essential roles of push and pull motivations that have influenced the decision to participate in Songkran Festival in Thailand. The research findings may benefit the suppliers in order to implement new strategies and plans; and travelers who would like to participate in Songkran Festival. Moreover, this also helps the perspective travelers to avoid the risk of dissatisfaction in their vacation.

\section{Limitation and Suggestion}

The study, however, has its own limitation: First of all, the survey was conducted only in Taiwan. Future research may study more in other regions or countries; second, this study only conducts the first-time Taiwanese tourists who have never participated in Songkran Festival in Thailand before; future study may conduct tourists' behavior before participation, during trip, or after participation in Songkran Festival. Moreover, the future study may specify more criteria and add more relevant tourist's characteristics, for example, travelling style, travel frequency to get more empirical validation because different travelers have the different perceptions of travel motivation. However, this study found interesting findings which inspired the future research to conduct an in-depth interview in order to get more accurate results and high-quality information.

\section{References}

Ajzen, I. (2001). Nature and operation of attitudes. Annual Review of Psychology, 52(1), 27-58.

Andale. (2012a). Pearson correlation: Definition and easy steps for use. Statistics How To. Retrieved from http://www.statisticshowto.com/what-is-the-pearson-correlation-coefficient

Andale. (2012b). Correlation coefficient formula: What is it? Statistics How To. Retrieved from http://www.statisticshowto.com/what-is-the-correlation-coefficient-formula

Asia News Monitor. (2010). Thailand: Songkran festival: One of the most significant elements of Thailand's cultural heritage. ProQuest Research Library. Retrieved from http://search.proquest.com/docview/1242141233?accountid=14526

Awaritefe, O. D. (2003). Destination environment quality and tourists' spatial behaviour in Nigeria: A case study of third world tropical Africa. International Journal of Tourism Research, 5(4), 251-268.

Bachleitner, R., \& Zins, A. H. (1999). Cultural tourism in rural communities: The residents' perspective. Journal of Business Research, 44(3), 199-209.

Beard, J. G., \& Ragheb, M. G. (1983). Measuring leisure motivation. Journal of Leisure Research, 15(3), 219-228.

Bowen, D., \& Clarke, J. (2009). Contemporary tourist behaviour: Yourself and others as tourists. Wallingford: CAB International.

Business Monitor International. (2014). Thailand tourism report Q1 2015. Market Research. Retrieved from http://www.marketresearch.com/Business-Monitor-International-v304/Thailand-Tourism-Q1-8537709/

Canny, I., \& Hidayat, N. (2012). The influence of service quality and tourist satisfaction on future behavioral intentions: The case study of Borobudur temple as a UNESCO world culture heritage destination. International Proceedings of Economics Development \& Research, 50, 89-97.

Chaipinit, W., \& Phetvaroon, K. (2011). Motivation and behaviour of Thai outbound tourists to Europe. Journal of Tourism, Hospitality \& Culinary Arts, 3(1), 99-109.

Chen, C. F., \& Tsai, D. (2007). How destination image and evaluative factors affect behavioral intentions. Tourism Management, 28(4), 1115-1122.

Chon, K. S. (1989). Understanding recreational traveler's motivation, attitude and satisfaction. The Tourist Review, $44(1)$, 3-7.

Dann, G. M. S. (1977). Anomie, ego-enhancement and tourism. Annals of Tourism Research, 4(4), 184-194. 
Eastman, E. (n.d.). Songkran: Thailand's water festival. The Culture Trip. Retrieved from http://theculturetrip.com/asia/thailand/articles/songkran-thailand-s-water-festival/

Geladi, P., \& Kowalski, B. R. (1986). Partial least-squares regression: A tutorial. Analytica Chimica Acta, 185, 1-17.

Jimmy, M. (2015). Songkran 2015 in Bangkok. Asia Web Direct. Retrieved from http://www.bangkok.com/information-festivals/songkran.htm\#

Kanagaraj, C., \& Bindu, T. (2013). An analysis of push and pull travel motivations of domestic tourists to Kerala. International Journal of Management and Business Studies, 3(2), 112-118.

Kaplanidou, K., \& Vogt, C. (2006). A structural analysis of destination travel intentions as a function of web site features. Journal of Travel Research, 45(2), 204-216.

Kassean, H., \& Gassita, R. (2013). Exploring tourists push and pull motivations to visit Mauritius as a tourist destination. African Journal of Hospitality, Tourism and Leisure, 2(3), 1-13.

Khuong, M. N., \& Ha, H. T. (2014). The influences of push and pull factors on the international leisure tourists' return intention to Ho Chi Minh city, Vietnam: A mediation analysis of destination satisfaction. International Journal of Trade, Economics and Finance, 5(6), 490-496. doi: 10.7763/IJTEF.2014.V5.421

Kim, K. (2008). Analysis of structural equation model for the student pleasure travel market: Motivation, involvement, satisfaction, and destination loyalty. Journal of Travel \& Tourism Marketing, 24(4), 297-313.

Lam, T., \& Hsu, C. H. C. (2006). Predicting behavioral intention of choosing a travel destination. Tourism Management, 27(4), 589-599.

Lee, S., Jeon, S., \& Kim, D. (2011). The impact of tour quality and tourist satisfaction on tourist loyalty: The case of Chinese tourists in Korea. Tourism Management, 32(5), 1115-1125.

Lonely Planet. (2013). Songkran: Tips for enjoying Thailand's water festival. Retrieved from http://www.lonelyplanet.com/asia/travel-tips-and-articles/76374

Mazumder, M. N. H., Sultana, M. A., \& Al-Mamun, A. (2013). Regional tourism development in Southeast Asia. Transnational Corporations Review, 5(2), 60-76.

Mill, R. C., \& Morrison, A. M. (1998). The tourism system: An introductory text (3rd ed.). Dubuque, Iowa: Kendall/Hunt Publishing Company.

Ministry of Tourism and Sports of Thailand. (2014). The summary of tourism in Thailand during January - December 2014. Annual report 2014. Retrieved from http://newdot2.samartmultimedia.com/home/details/11/222/24095

Mohammad, B. A., \& Som, A. P. (2010). An analysis of push and pull travel motivations of foreign tourists to Jordan. International Journal of Business and Management, 5(12), 41-50.

Moutinho, L. (2000). Trends in tourism. In L. Moutinho (Ed.), Strategic management in tourism. Wallingford: CAB International.

Nankervis, A., \& Kelly, I. (2001). Visitor destinations. Sydney, Australia: John Wiley \& Sons.

National Culture Commission. (2007). How to celebrate Songkran. Thailand Life. Retrieved from http://www.thailandlife.com/songkran-festival/how-to-celebrate-songkran.html

Ng, S. I., Lee, J. A., \& Soutar, G. N. (2007). Tourists' intention to visit a country: The impact of cultural distance. Tourism Management, 28(6), 1497-1506.

Niemelä, T. (2010). Motivation factors in dark tourism. Case: House of terror (Bachelor's thesis, Lahti University of Applied Sciences, Finland). Retrieved from http://publications.theseus.fi/bitstream/handle/10024/14984/Niemela_Titta.pdf

Popichit, N., Anuwichanont, J., Chuanchom, J., Serirat, J., \& Mechinda, P. (2013). A survey of destination potential, tourism activities and future travelling intention towards tourism along the rivers in Phra Nakhon Si Ayutthaya province. International Journal of Business and Social Science, 4(7), 116-122.

Pramotmaneerat, T. (2014). Special report: Songkran festival celebrated in all corners of Thailand. National News Bureau of Thailand. Retrieved from http://thainews.prd.go.th/centerweb/newsen/NewsDetail?NT01_NewsID=WNECO5704120010001

Pratminingsih, S. A., Rudatin, C. L., \& Rimenta, T. (2014). Roles of motivation and destination image in predicting tourist revisit intention: A case of Bandung - Indonesia. International Journal of Innovation, Management and Technology, 5(1), $19-24$.

Qiao, G., Chen, N., Guan, Y., \& Kim, S. (2008). Study on Chinese tourists' motivation and satisfaction to visit South Korea. International Journal of Tourism Sciences, 8(1), 17-38.

Singh, A. (1997). Asia pacific tourism industry: Current trends and future outlook. Asia Pacific Journal of Tourism Research, 2(1), 89-99. doi: 10.1080/10941669808721988 
Sirakaya, E., Sheppard, A. G., \& McLellan, R. W. (1997). Assessment of the relationship between perceived safety at a vacation site and destination choice decisions: Extending the behavioural decision-making model. Journal of Hospitality and Tourism Research, 21(2), 1-10.

Sparks, B. A. (2007). Planning a wine tourism vacation? Factors that help to predict tourist behavioral intentions. Tourism Management, 28(5), 1180-1192.

Sudipta, K. S., Sarat, K. L., \& Babu, G. P. (2010). Cultural tourism in Malaysia in the perspective of Indian tourists: A study. Journal of Tourism, 10(10), 48-53.

Suksawat, S. (n.d.). Happy New Year Songkran Festival. Thaiways Magazine. Retrieved from http://www.thaiwaysmagazine.com/thai_article/2101_songkran_festival/songkran_festival.html

Tang, Y. (2014). Travel motivation, destination image and visitor satisfaction of international tourists after the 2008 Wenchuan earthquake: A structural modelling approach. Asia Pacific Journal of Tourism Research, 19(11), 1260-1277.

Tourism Authority of Thailand [TAT]. (2014). Thailand remains a popular destination among travellers from Taiwan. Retrieved from http://www.tatnews.org/thailand-remains-a-popular-destination-among-travellers-from-taiwan

Vanhaleweyk, G. (2014). Thailand: Tourist arrivals from 1998 till 2014. Retrieved from http://www.thaiwebsites.com/tourism.asp

World Tourism Organization. (2004). Technical seminar on cultural tourism and poverty alleviation. Retrieved from http://sdt.unwto.org/sites/all/files/pdf/cambodia_finrep.pdf

World Travel \& Tourism Council. (2014). Economic impact 2014 Thailand. WTTC. Retrieved from http://www.wttc.org/-/media/files/reports/economic\%20impact\%20research/country\%20reports/thailand2014.pdf

Yiamjanya, S., \& Wongleedee, K. (2014). International tourists' travel motivation by push-pull factors and the decision making for selecting Thailand as destination choice. International Scholarly and Scientific Research \& Innovation, 8(5), 1348-1353.

Zeithaml, V. A., Bitner, M. J., \& Gremler, D. (2009). Services marketing: Integrating customer focus across the firm (5th ed.). New York, NY: McGraw-Hill. 